\title{
PRÁTICAS DE ANÁLISE LINGUísticA: UMA ANÁLISE EM LIVRO DIDÁTICO
}

\author{
LINGUISTIC ANALYSIS PRACTICES: \\ AN ANALYSIS IN DIDACTIC BOOKS
}

\author{
Laís França Campos Rocha | Lattes | campos.laisf@gmail.com \\ Universidade Federal do Paraná
}

Resumo: Considerando o livro didático como um dos principais materiais com que conta o professor em sala de aula, o presente artigo objetiva analisar como é desenvolvida a análise linguística em materiais didáticos de Língua Portuguesa. Para isso, este trabalho realiza a leitura crítica das atividades de análise linguística propostas no livro didático, versão do aluno, intitulado Língua Portuguesa: linguagem e interação, de Carlos Emílio Faraco, Francisco Marto de Moura e José Hamilton Maruxo Júnior, da Editora Ática, do $1^{\circ}$ ano do Ensino Médio, aprovado no Programa Nacional do Livro Didático (PNLD) de 2015. Sustentando-se teoricamente em autores como Geraldi (2003a), Franchi (1997) e Marcuschi (2002), que tratam das teorias relacionadas à concepção interacionista de ensino de língua, entende-se a análise linguística ao lado das demais práticas (leitura, oralidade e produção escrita), como unidade de ensino na qual se analisam os recursos expressivos da língua, isto é, aspectos gramaticais, discursivos, estilísticos, pragmáticos, fonológicos, entre outros, relacionados a um gênero textual situado no discurso (GERALDI, 2003b). Nesta pesquisa, as análises limitam-se à seção Prática de linguagem do referido livro didático, uma vez que sua proposta é, entre outras, a de promover reflexão sobre o uso da língua. Das 12 seções Prática de linguagem, serão destacadas quatro seções e suas respectivas análises, a fim de que sejam discutidas tanto as atividades que apresentam características que qualificam a prática de análise linguística quanto aquelas que não as apresentam. Constatou-se, no livro analisado, que a prática de análise linguística é pouco desenvolvida na seção que se propõe a fazê-la.

Palavras-chave: Livro didático; Ensino de Língua Portuguesa; Análise linguística. 
Abstract: Considering the textbook as one of the main materials used by the teacher in the classroom, this article aims to analyze how linguistic analysis is developed in didactic materials of Portuguese Language. For this, this work carries out the critical reading of the activities of linguistic analysis proposed in the didactic book, in the student's version, entitled Língua Portuguesa: linguagem e interação, by Carlos Emílio Faraco, Francisco Marto de Moura and José Hamilton Maruxo Júnior, from the Publishing company Ática, from the 1st year of High School, approved in the Programa Nacional do Livro Didático (PNLD) of 2015. This work is based on authors such as Geraldi (2003a), Franchi (1997) and Marcuschi (2002), which deal with theories related to the interactionist conception of language teaching, which understands linguistic analysis alongside other practices (reading, orality and production writing), as a unit of education in which the expressive resources of the language are analyzed, that is, grammatical, discursive, stylistic, pragmatic, phonological aspects, among others, related to a textual genre situated in the discourse (GERALDI, 2003b). In this research, the analyses are limited to the Prática de linguagem section of this textbook, since its proposal is, among others, to promote reflection on the use of the language. From the 12 sections Prática de linguagem, four sections and their respective analyzes will be highlighted, in order to discuss both the activities that have characteristics that qualify the practice of linguistic analysis, and those that do not present them. It was found in the book analyzed the practice of linguistic analysis is scarcely developed in the section that proposes to do it.

Keywords: Textbook; Portuguese language teaching; Linguistic analysis.

\section{Introdução}

Segundo Borges (2012), historicamente, o ensino de português confunde-se com o ensino da gramática do português, considerada tradicionalmente o assunto por excelência da disciplina de Língua Portuguesa. No passado, essa realidade era compreensível, uma vez que somente uma classe privilegiada, que já dominava a norma padrão, tinha acesso à escola e o que restava a ser aprendido era a gramática, hoje denominada tradicional porque se trata de: “[...] uma visão teórica sobre a linguagem surgida na antiguidade clássica e que constitui a base teórica da quase totalidade das gramáticas até praticamente o século XXI" (BORGES, 2012, p. 3). 
A partir de 1970, houve uma mudança no discurso sobre o currículo da disciplina, isto é, iniciou-se um movimento contra a gramática e a favor de sua substituição por atividades ligadas ao texto. Embora esse movimento tenha despertado novas interpretações para o ensino de Língua Portuguesa, conforme destaca Borges (2012), ainda não houve uma mudança efetiva na sala de aula: a gramática tradicional continua sendo privilegiada no contexto de ensino da língua materna.

Um dos fatores da permanência da gramática tradicional na escola está no material de apoio com que conta o professor, como livros didáticos e dicionários, que são invariavelmente construídos sobre a perspectiva teórica da gramática tradicional. Assim,

\footnotetext{
[p]rofessores que não são preparados para ensinar outra coisa que não a gramática, materiais didáticos e de consulta que privilegiam a teoria tradicional e, contraditoriamente, um discurso de que não se deve ensinar gramática na escola são fatores parcialmente responsáveis pelo caos a que o ensino de Língua Portuguesa atingiu. (BORGES, 2012, p. 4).
}

Nesse contexto, Bagno (2007) considera o livro didático um dos elementos que compõem, juntamente com a gramática tradicional e os métodos tradicionais de ensino, o círculo vicioso do preconceito linguístico, que se forma desta maneira: “[...] a gramática tradicional inspira a prática de ensino, que por sua vez provoca o surgimento da indústria do livro didático, cujos autores - fechando o círculo - recorrem à gramática tradicional como fonte de concepções e teorias sobre a língua” (BAGNO, 2007, p. 72-73).

Diante de muitas discussões acerca do ensino de gramática na escola, concluiu-se que a questão não é "se ela deve ou não ser ensinada” e sim "para quê e como ensiná-la”. Partindo da necessidade de se inovarem as propostas de ensino de gramática, Geraldi (2003b) cunhou a expressão "análise linguística”, o que contribuiu para denominar uma nova perspectiva de reflexão sobre o sistema linguístico e sobre os usos da língua.

Nesse contexto de mudanças na área de pesquisa e ensino de língua, o consenso foi de que o ensino de gramática não deve excluir os pressupostos da normatividade, mas também não há de limitar os conceitos àquela visão, para, assim, levar o ensino de Língua Portuguesa enquanto gramática a contribuir com a

[...] formação de usuários competentes da língua, capazes de, em situações específicas de interação comunicativa, produzir textos (orais e/ou escritos) que sejam adequados à produção de determinados efeitos de sentido para a consecução de dada intenção [...] e ao mesmo tempo, capazes de compreender os textos (orais e/ou escritos) que recebem, estabelecendo/percebendo sentido(s) adequado(s) à forma como cada 
texto se apresenta construído, ao contexto sócio-histórico-ideológico e à situação imediata de comunicação em que ele está sendo utilizado como meio ou instrumento para a comunicação. (TRAVAGLIA, 1996, p. 9697).

Desse modo, a fim de analisar como é desenvolvida a análise linguística em materiais didáticos de Língua Portuguesa, o presente artigo toma como base a concepção interacionista de ensino de língua e seleciona para estudo o livro didático Língua Portuguesa: linguagem e interação, de Carlos Emílio Faraco, Francisco Marto de Moura e José Hamilton Maruxo Júnior, da Editora Ática, aprovado em 2015 pelo Programa Nacional do Livro Didático (PNLD).

O estudo do referido material teve como recorte apenas as seções Prática de linguagem da versão do aluno, uma vez que sua proposta é, entre outras, a de promover reflexão sobre o uso da língua. Das 12 seções Prática de linguagem, serão destacadas quatro seções e suas respectivas análises, a fim de que sejam discutidas tanto as atividades que apresentam características que qualificam a prática de análise linguística quanto aquelas que não as apresentam.

\section{Prática de análise linguística}

A análise linguística pode ser situada como uma das práticas discursivas propostas na perspectiva interacionista, sendo as demais: leitura, oralidade e produção escrita. Geraldi (2001, p. 88) defende-as de forma integrada:

Essas práticas, integradas, no processo de ensino-aprendizagem, têm dois objetivos interligados:

a) tentar ultrapassar, apesar dos limites da escola, a artificialidade que se institui na sala de aula quanto ao uso da linguagem;

b) possibilitar, pelo uso não artificial da linguagem, o domínio efetivo da língua padrão em suas modalidades oral e escrita.

O trabalho com a análise e reflexão da língua passa a constituir, portanto, uma das práticas fundamentais para que os alunos sejam formados como cidadãos conscientes da complexidade da dinâmica social, das múltiplas escalas de valores empregadas a todo o momento nas relações com outras pessoas por meio da linguagem.

Segundo Bezerra (2013, p. 33), "instituída como eixo de ensino, a prática de análise linguística não tem sido abordada na mesma proporção em que o são os eixos de leitura e escrita”. Desse modo, a autora reconhece uma ruptura nos materiais didáticos: 
De um lado, há a inovação das abordagens de leitura e escrita, fundamentadas em perspectivas teóricas enunciativas, e, de outro, constatamos, de modo geral, o estudo do componente linguístico à luz da norma e/ou da descrição estrutural, sem estabelecer uma relação com o plano textual-enunciativo. (BEZERRA, 2013, p. 34)

A proposta dos PCN para o eixo de análise linguística desloca o enfoque da palavra ou frase (proposta pela gramática tradicional) para a análise do texto, influenciada pelas teorias linguísticas textuais e enunciativas, resultando em novos objetos de estudo. Assim,

[o] que deve ser ensinado não responde às imposições de organização clássica de conteúdos na gramática escolar, mas aos aspectos que precisam ser tematizados em função das necessidades apresentadas pelos alunos nas atividades de produção, leitura e escuta de textos. $\mathrm{O}$ modo de ensinar, por sua vez, não reproduz a clássica metodologia de definição, classificação e exercitação, mas corresponde a uma prática que parte da reflexão produzida pelos alunos mediante utilização de uma terminologia simples e se aproxima, progressivamente, pela mediação do professor, do conhecimento gramatical produzido. Isso implica, muitas vezes, chegar a resultados diferentes daqueles obtidos pela gramática tradicional, cuja descrição, em muitos aspectos, não corresponde aos usos atuais da linguagem, o que coloca a necessidade de busca de apoio em outros materiais e fontes. (BRASIL, 1998, p. 29).

Nesse contexto, os PCN de Língua Portuguesa explicitam que as atividades de análise linguística incitam reflexão sobre a linguagem, têm o texto como unidade básica de ensino e podem ser classificadas quanto aos seus fins, a saber: atividades epilinguísticas e atividades metalinguísticas.

Franchi (1987) entende a atividade epilinguística como a prática consciente e estimulada da linguagem proveniente da reflexão que todo falante natural de uma língua realiza. Uma análise epilinguística ocorre, portanto, quando há operação sobre a própria linguagem, isto é, a comparação de expressões, atribuição de novas significações às formas linguísticas, seleção dos recursos linguísticos que melhor se ajustam às intenções comunicativas, entre outras ações do usuário da língua. Para Travaglia (2001), as atividades epilinguísticas podem ou não ser conscientes, o que significa que a atividade “[...] inconsciente se relaciona com a gramática de uso [...]” (TRAVAGLIA, 2001, p. 34), e o “[...] consciente parece se aproximar mais da gramática reflexiva, todavia, de qualquer forma há uma reflexão sobre os elementos da língua e de seu uso relacionada ao processo de interação comunicativa."

Ainda segundo Franchi (1987), as atividades metalinguísticas podem ser caracte- 
rizadas como uma análise sistemática em que se objetiva tratar sobre a própria língua, descrevendo-a em quadro nocional intuitivo ou teórico. Assim, é por meio da metalinguagem que se torna possível trabalhar com conceitos e nomenclaturas que descrevem os fenômenos linguísticos. Entretanto, esse é apenas o tipo de reflexão adotado na orientação do ensino tradicional de língua.

Por outro lado, na perspectiva da análise linguística, Silva (2010, p. 955) explica que:

[a]s atividades escolares devem partir do uso efetivo da língua, entendido aqui como o exercício pleno, circunstanciado e com intenções significativas da própria linguagem, para a reflexão epilinguística e desta para a metalinguística, para, depois, tornar ao uso. Assim, dizemos que a AL configura-se como uma prática de ensino que tem o uso da linguagem como seu ponto de partida e de chegada.

Conforme afirmam alguns linguistas (GERALDI, 2006; BAGNO, 2011), o trabalho com a análise linguística como atividade metalinguística não diz respeito à "gramática contextualizada" - expressão que tem aparecido no discurso de vários autores de LD -, que se resume no tradicional ensino de nomenclaturas e classes gramaticais, por meio do uso do texto, ou seja, o texto apenas como pretexto para ensinar gramática tradicional do qual ocorre a extração de palavras e frases para se trabalharem questões sistemáticas da língua.

Sobre as atividades metalinguísticas, Geraldi (2002, p. 63-64) destaca:

Todas essas considerações mostram a necessidade de transformar a sala de aula em um tempo de reflexão sobre o já-conhecido para aprender o desconhecido e produzir o novo. É por isso que atividades de reflexão sobre a linguagem (atividades epilinguísticas) são mais fundamentais do que aplicação a fenômenos sequer compreendidos de uma metalinguagem de análise construída pela reflexão de outros. Aquele que aprendeu a refletir sobre a linguagem é capaz de compreender uma gramática - que nada mais é do que o resultado de uma (longa) reflexão sobre a língua; aquele que nunca refletiu sobre a linguagem pode decorar uma gramática, mas jamais compreenderá seu sentido.

Conforme ressalta Bezerra (2013), essa concepção de análise linguística como um conjunto de atividades epilinguísticas e metalinguísticas, por meio de um processo de didatização, chega aos livros didáticos ancorada na tradição gramatical, em teorias linguísticas ou na mescla dessas duas orientações. 
A ação de pensar e falar sobre a linguagem constitui, assim, uma atividade de natureza reflexiva, ou seja, quando há interação, há sempre uma atividade de reflexão e, portanto, uma atividade de análise linguística. Na prática pedagógica dessa perspectiva, parte-se da palavra e da contrapalavra do aluno e do professor, ou seja, os papéis de docente e discente são deslocados para a condição de interlocutores, pois se considera que o sujeito está no centro da linguagem e a significação só se constitui no discurso.

Consideram-se atividades de análise linguística aquelas que favorecem ao aluno a compreensão da língua em situação de interação. Isso é possível, por exemplo, por meio de perguntas como: por que se escreveu de tal forma nesse texto? Qual o efeito de sentido provocado por determinada palavra naquela situação de uso? Como organizar determinada ideia, tendo em vista o gênero selecionado? As respostas são encontradas quando professor e aluno refletem sobre a organização da língua dentro de determinado contexto de uso.

Ora, sabe-se que o professor tem necessidade de orientação nesse sentido, tanto quanto o discente, portanto o LD representa relevante recurso de apoio à formação docente se o autor propuser, neste caso, o encaminhamento da análise linguística de forma adequada.

É fundamental analisar a língua sem separá-la de seu contexto enunciativo, visando garantir o viés metodológico proposto por Bakhtin, uma vez que a "enunciação só se realiza no curso da comunicação verbal, pois o todo é determinado pelos seus limites, que se configuram pelos pontos de contato de uma determinada enunciação com o meio extraverbal e verbal” (BAKHTIN, 2004, p. 125). Por isso, mesmo ao tratar da gramática, é preciso procurar garantir as relações significativas estabelecidas pelos elementos linguísticos analisados.

\section{Analisando a proposta de análise linguística do livro didático}

No manual do professor do material analisado, os autores assim descrevem a seção Prática de linguagem:

Essa seção procura amarrar o estudo textual e gramatical proposto em cada unidade. Nela, há duas ordens de atividades: as de reflexão sobre o uso da língua (questões que levam os alunos a analisar textos e a perceber como as estruturas da língua se manifestam "na prática") e as de produção orientada (textos produzidos com base na utilização das estruturas linguístico-discursivas e gramaticais estudadas). 
Não se trata de uma seção extensa, mas as atividades nela propostas podem demandar bastante tempo de realização. Convém, portanto, que o professor esteja atento a esse fato antes de sugerir aos alunos sua realização. Essas atividades partem progressivamente do enunciado para o texto e em alguns casos constituem autênticos exercícios de análise linguística cujo objetivo é levar os alunos a refletir sobre suas próprias práticas de linguagem, aprendendo a adaptá-las à situação de comunicação em pauta. (FARACO; MOURA; MARUXO JÚNIOR, 2013, p. 391, grifos nossos).

Assim, a seção Prática de linguagem apresenta duas ordens de atividades: as que possibilitam aos alunos a análise de textos e a percepção de como as estruturas linguísticas funcionam na prática, e as que orientam a produção de textos com base na utilização das estruturas linguístico-discursivas e gramaticais estudadas.

A seção selecionada para análise está presente nas páginas finais de cada capítulo do livro do aluno, totalizando doze vezes. Desse número total, por questão de espaço, foram selecionadas quatro seções, as quais têm sintetizados no quadro a seguir os tópicos concernentes ao conteúdo, às atividades propostas na prática de linguagem e às características que qualificam essa prática. A síntese das informações que se referem ao conteúdo trabalhado na seção é importante para a compreensão de quais elementos linguísticos fizeram parte dos objetivos de estudo da seção. Verificou-se que os autores optaram por explicitar no título das seções os conteúdos a serem enfocados nas atividades.

\begin{tabular}{|l|l|l|c|c|c|}
\hline \multicolumn{5}{|c|}{ Quadro sinóptico da seção Prática de linguagem } \\
\hline \multirow{2}{*}{$\begin{array}{l}\text { Subtítulo da seção/ descri- } \\
\text { ção do conteúdo }\end{array}$} & Atividades propostas & \multicolumn{2}{|c|}{ Características que qualificam } \\
a análise linguística
\end{tabular}




\begin{tabular}{|c|c|c|c|c|c|}
\hline \multirow{4}{*}{$\begin{array}{l}\text { Subtítulo: "Nominalização" } \\
\text { Conteúdo: a seção explora o } \\
\text { processo de nominalização } \\
\text { das palavras. }\end{array}$} & $\begin{array}{l}\text { Atividade 1: com base na análise } \\
\text { de duas linhas de um texto lido an- } \\
\text { teriormente, são retomados con- } \\
\text { ceitos gramaticais. }\end{array}$ & $x$ & $x$ & --- & $\checkmark$ \\
\hline & $\begin{array}{l}\text { Atividades } 2 \text { e 3: propõe-se a re- } \\
\text { escrita de orações previamente } \\
\text { dadas, de modo que os trechos em } \\
\text { destaque sejam nominalizados. }\end{array}$ & $x$ & $x$ & --- & $\checkmark$ \\
\hline & $\begin{array}{l}\text { Atividade 4: propõe-se uma pes- } \\
\text { quisa em reportagens de revistas } \\
\text { de casos de nominalização. }\end{array}$ & --- & $\checkmark$ & --- & $\checkmark$ \\
\hline & $\begin{array}{l}\text { Atividade 5: com base na leitura } \\
\text { de um texto, propõe-se a cons- } \\
\text { trução de um quadro cronológico } \\
\text { com verbos e orações nominaliza- } \\
\text { dos. }\end{array}$ & --- & $\checkmark$ & --- & $\checkmark$ \\
\hline \multirow{2}{*}{$\begin{array}{l}\text { Subtítulo: "Modalização e ad- } \\
\text { vérbios" } \\
\text { Conteúdo: a seção explora a } \\
\text { classe dos advérbios. }\end{array}$} & $\begin{array}{l}\text { Atividade 1: propõe-se que os alu- } \\
\text { nos analisem as expressões desta- } \\
\text { cadas (advérbios) na entrevista } \\
\text { presente na seção. }\end{array}$ & --- & $\checkmark$ & $\checkmark$ & $\checkmark$ \\
\hline & $\begin{array}{l}\text { Atividade 2: propõe-se a produção } \\
\text { de um parágrafo com, no mínimo, } \\
\text { três advérbios ou expressões ad- } \\
\text { verbiais. }\end{array}$ & $x$ & $x$ & --- & $x$ \\
\hline $\begin{array}{l}\text { Subtítulo: "Valor social das } \\
\text { palavras" } \\
\text { Conteúdo: a seção aborda o } \\
\text { nível formal e informal da lin- } \\
\text { guagem, com base no enun- } \\
\text { ciador. }\end{array}$ & $\begin{array}{l}\text { Os alunos são orientados a rees- } \\
\text { crever os trechos do texto lido } \\
\text { anteriormente, com a mudança de } \\
\text { enunciador. }\end{array}$ & \pm & $\checkmark$ & --- & $\checkmark$ \\
\hline
\end{tabular}

\section{Leganda}

$\checkmark$ Usado quando a resposta é positiva em relação à presença do item verificado.

\pm Usado quando o item em questão está parcialmente presente, isto é, nem todas as questões permitem constatar a presença do item verificado.

$X$ Usado quando a resposta é negativa em relação ao item verificado.

--- Não cabe essa característica na atividade proposta.

Antes de prosseguir com a leitura crítica de cada seção, destaca-se a importância de esclarecer a metodologia de análise estabelecida, descrita na subseção a seguir. 


\subsection{Metodologia de análise}

Para análise de cada seção Prática de linguagem, consideraram-se as características que qualificam a prática de linguagem no âmbito das especificidades relacionadas aos gêneros textuais trabalhados nas seções, isto é, as condições de produção, a autenticidade dos textos e a relação estabelecida entre a língua oral e escrita. Além disso, as especificidades do gênero dizem respeito à estrutura composicional dos textos e o estilo - as escolhas lexicais, sintáticas e formais em função do gênero e da situação de interlocução estabelecida.

As condições de produção são concebidas por estudiosos da Linguística de texto, como Marcuschi (2008), como características básicas do contexto interlocutivo acionadas pelos sujeitos, de forma consciente ou inconsciente, no decorrer do processo de elaboração do texto oral ou escrito. De forma geral, as condições às quais o produtor de textos precisa atender estão relacionadas aos seguintes aspectos: conteúdo temático (assunto tratado no texto), interlocutor pretendido (público ao qual o texto se dirige), objetivo a ser atingido (propósito que motiva a produção), gênero textual próprio da situação de comunicação e suporte em que o texto estará veiculado.

Com relação à autenticidade analisada nos textos, destaca-se que esse termo é usado em oposição à linguagem artificial criada para um fim específico, geralmente para o ensino de conteúdos gramaticais. Dessa forma, um texto autêntico possibilita a análise da linguagem e a percepção das estratégias discursivas com que se tecem os diferentes gêneros em situações naturais de comunicação.

Considerando que as relações entre oralidade e escrita se dão num contínuo, e não na observação dicotômica de características polares, esse aspecto é analisado nas atividades a fim de verificar se a relação oral/escrito é estabelecida de modo a levar os alunos a compreenderem que tanto a fala quanto a escrita seguem o mesmo sistema linguístico, ou seja, as variações decorrentes de cada tipo de uso do sistema se devem a estratégias de seleção de possibilidades do próprio sistema.

A estrutura composicional e o estilo dos textos também foram considerados na análise pelo fato de cada gênero textual trabalhado nas seções apresentar escolhas lexicais e sintáticas apropriadas às situações de interlocução estabelecidas.

\subsection{Análise 1: Expressões que marcam o ritmo da narrativa}

Esta seção encerra o primeiro capítulo do material, intitulado "Conto". Conforme é possível conferir no anexo 1, são propostas, basicamente, duas atividades. Na primeira 
atividade, a prática de análise linguística é explorada por meio de um dos critérios para a produção do texto escrito. No entanto, a proposta de produção escrita está dentro dos moldes tradicionais de ensino de língua, ou seja, o aluno é orientado a escrever um texto com base na observação de uma imagem:

1 Observe a imagem a seguir e imagine uma história sobre ela que faça sentido.

[...]

a) Inicie, numa folha avulsa, uma narrativa contando o que ocorre com as personagens da tela.

b) Nessa narrativa, promova um retorno temporal para explicar um fato que antecedeu ao momento representado na pintura.

c) Controle o ritmo de sua narrativa, inserindo sequências de aceleração ou retardamento.

d) Se quiser, insira descrições ou diálogos, para ajudar a construir o ritmo indicado.

(FARACO; MOURA; MARUXO JÚNIOR, 2013, p. 40).

As condições de produção não são totalmente atendidas, pois os autores só dispõem de um conteúdo temático baseado na imagem e do tipo textual a ser seguido (narrativo), sem a indicação de um interlocutor pretendido, objetivo a ser atingido e suporte em que o texto estará veiculado. Dessa maneira, o aluno escreve, a princípio, sem ter um porquê, um a quem ou um suporte ao qual seu texto estará vinculado.

Diferentemente da primeira atividade, a segunda apresenta um encaminhamento adequado para explorar o conteúdo linguístico pretendido porque possibilita que os alunos, em grupos, utilizem as expressões de aceleração e retardamento de modo autêntico, na prática oral, a fim de produzir uma história coletiva.

Ainda que os autores forneçam algumas expressões que auxiliarão os alunos a marcar o ritmo da narrativa criada - "Naquela manhã de agosto..., "E assim, durante os meses que se passaram..., "Logo em seguida..., “'Hoje..., "Mas dias antes...” e “De repente...”-, tal proposta também não atende todas as condições de produção, pois não estão determinados o conteúdo temático e o propósito a ser atingido, apenas o suporte (mural da classe) pressupõe os possíveis interlocutores (comunidade escolar).

Destaca-se, ainda, que na segunda atividade há a intenção de estabelecer uma relação oral/escrito, pois os alunos são orientados a registrar por escrito a história oral produzida coletivamente:

a) Procedam desta forma: um aluno começa a história, a partir da primeira expressão; um segundo aluno prossegue de onde o primeiro parou, 
utilizando a segunda expressão e dando continuidade à história; e assim por diante, até que todas as expressões tenham sido empregadas.

b) Depois do trabalho oral, a história criada coletivamente em cada grupo deve ser registrada por escrito, para ser comparada com o trabalho dos demais grupos. Exponham as narrativas no mural da classe.

(FARACO; MOURA; MARUXO JÚNIOR, 2013, p. 40).

No entanto, constata-se que a transposição do texto escrito para o oral objetiva apenas a comparação com o texto dos demais grupos, conforme está explícito no enunciado. O professor, por sua vez, não tem subsídio dos autores quanto ao possível trabalho dessa relação.

Conclui-se, assim, que a primeira atividade da seção analisada não desenvolve a análise linguística por parte do aluno porque apresenta somente uma proposta de produção textual, que não atende a todas as condições de produção e que não apresenta orientações que direcionem a uma análise dos elementos linguísticos empregados. Quanto à segunda proposta de produção, verifica-se que, embora tenha a intenção de relacionar a língua oral à escrita, não apresenta direcionamentos que possibilitem aos alunos a percepção das características próprias de cada modalidade. Além disso, também não atende a todas as condições de produção.

\subsection{Análise 2: Nominalização}

A seção com o tema "Nominalização" (anexo 2) buscou encerrar o quarto capítulo, intitulado "Narrativa histórica”. Embora o tema "nominalização" pertença à Linguística Textual, constata-se que o encaminhamento da seção sustenta-se sobre a Gramática Tradicional, conforme se lê na primeira atividade, presente na primeira página do anexo 1.

Embora os exercícios objetivem a retomada dos conteúdos gramaticais estudados no capítulo, eles o fazem de modo tradicional, em que a identificação da classe gramatical das palavras é feita por meio da leitura no nível da frase, e não do parágrafo. Dessa maneira, ao indicar as linhas entre parênteses, o aluno não é levado a refletir sobre o parágrafo, mas, sim, é conduzido a analisar a função do período apenas, ou seja, de uma frase, sendo visto como um depositário de nomenclaturas e regras, não um usuário da língua.

Retomando o texto (anexo 3), é possível verificar que, no parágrafo anterior àquele de onde foi extraído o trecho destacado no exercício, a palavra "morar" possibilita que a atividade explorasse a nominalização de verbos, já que no trecho há o substantivo "morada”. Assim, em vez de dar destaque a dois adjetivos, a atividade poderia abordar outra 
forma de nominalização, no plano do parágrafo. A primeira atividade, portanto, trabalha basicamente o conhecimento das nomenclaturas memorizadas, não mobilizando o raciocínio do aluno, que o levaria para a análise do texto como unidade complexa de sentidos, fazendo-o perceber o referente e os termos que a ele se referem.

É importante ressaltar que o texto retomado pelo exercício tem sua autenticidade comprometida por conta de sua supressão e de sua diagramação, como pode ser visto na quarta e quinta página do anexo 2 deste trabalho. Além do texto, nas páginas estão presentes dois boxes de glossário, um quadro com comentários sobre a coleção na qual se encontra o texto, duas imagens e um quadro com informações sobre pessoas mencionadas no texto. Essa "poluição" gerada pela diagramação prejudica o aprendizado do aluno no que tange à compreensão do gênero textual em questão.

Em continuação, a seção expõe um trecho explicativo sobre nominalização. Os autores optam, nesse momento, por conceituar o termo "nominalização" por meio de uma gramática da frase, sem que haja menção à nominalização como importante mecanismo de coesão textual. Desse modo, o aluno tem acesso a conceitos linguísticos na perspectiva tradicional, isto é, o conceito é exemplificado por meio de frases descontextualizadas.

Não há, nesse sentido, uma proposta de prática de análise de nominalização em textos para que haja a compreensão desse mecanismo no uso, mas, sim, um exercício de reescrita de frases elaboradas exclusivamente para atender à atividade, porém sem estarem situadas em um parágrafo autêntico, extraído de um texto publicado, como pode ser lido na segunda e na terceira atividades da seção.

Tais atividades tradicionais do tipo "siga o exemplo" não constituem práticas de análise linguística, mas alinham-se à perspectiva estruturalista, já que propõem aos alunos a reescrita mecânica de frases que requerem as mesmas modificações ditadas pelo exemplo previamente fornecido.

Por fim, trechos extraídos de matérias de revistas embasam o quarto exercício da seção.

Embora o exercício de pesquisa e identificação de nominalização em textos do cotidiano seja importante, a seção não possibilita ao aluno a prática dessa estratégia no desenvolvimento de seu próprio texto, mas o reconhecimento de diferentes tipos de nominalização em trechos autênticos, o que já representa uma prática mais adequada, porém em nível de compreensão e não de aplicação. No caso da última atividade, com base em um texto adaptado da revista Época, o aluno é orientado a produzir fragmentos de textos para compor um quadro cronológico, conforme uma sugestão, que cabe, mais uma vez, como exemplo. 
Conclui-se a análise da primeira seção selecionada destacando que, embora no manual do professor esteja claro o objetivo de levar o aluno a perceber como as estruturas da língua se manifestam "na prática"; no livro do aluno, nota-se, nas atividades da primeira seção analisada, que os alunos são orientados a perceber fenômenos linguísticos em fragmentos desvinculados do texto como um todo.

Como ressalta Marcuschi (2008), se, por um lado, é possível realizar enunciados completos e explicá-los com gramáticas de frase, tomando-os independentemente, por outro, sabe-se que vários enunciados corretamente construídos, quando postos em sequência imediata, podem não formar uma sequência aceitável. É justamente essa noção, ausente na seção, que deveria estar sendo desenvolvida por meio de atividades que promovessem a análise e, posteriormente, a prática dos requisitos essenciais à sequencialidade textual, como a coesão - conteúdo adequado à temática "nominalização".

\subsection{Análise 3: Modalização e advérbios}

A seção disponibiliza, logo no início (anexo 4), os conceitos de advérbio e de modalização. No entanto, tal exposição é feita por meio de três frases descontextualizadas, o que caracteriza o encaminhamento tradicional do ensino de língua.

É importante observar, ainda na primeira página da seção, disponível no anexo 4, que a ilustração, localizada no canto superior direito, não tem propósito algum, pelo contrário, parece estar apenas tampando o vazio que estaria em seu lugar. Mais uma vez, identifica-se uma característica do ensino tradicional de Língua Portuguesa, em que as imagens não são pensadas como elementos não verbais que possam contribuir para o entendimento do conteúdo trabalhado.

Na sequência, os autores dispõem para leitura uma entrevista adaptada, que servirá de base para as duas atividades da seção. Nesse texto, estão destacados os advérbios e as expressões adverbiais, que, no primeiro exercício, são mencionados no enunciado: “Tentem explicar de que maneira os advérbios e as expressões adverbiais do texto, destacados por nós, colaboraram para que os cientistas expusessem suas opiniões" (FARACO; MOURA; MARUXO JÚNIOR, 2013, p. 178). A orientação para o professor nessa atividade diz: "Professor, verifique hipóteses de resposta levantadas pelos alunos e se eles conseguem justificá-las. O importante aqui é começarem a perceber que a expressão de opinião, em textos de qualquer natureza, está associada a expressões modalizadoras” (FARACO; MOURA; MARUXO JÚNIOR, 2013, p. 178). 
Ainda que a atividade possibilite que os alunos pratiquem a análise linguística dos advérbios e das expressões adverbiais inseridos em um texto parcialmente autêntico, já que ele foi adaptado, tais elementos já são dados prontos por meio do destaque. Considera-se que a atividade seria mais bem explorada se os alunos buscassem identificá-los no texto, isto é, a atividade poderia possibilitar que os alunos usassem a dedução/ intuição que têm como usuários da língua para selecioná-los.

A segunda e última atividade da seção propõe a produção de um parágrafo com, no mínimo, três advérbios ou expressões adverbiais destacados na entrevista lida. Esse direcionamento é considerado limitador porque o aluno é levado a reproduzir os mesmos sentidos expressos no texto lido. O tema lançado no enunciado segue o mesmo conteúdo da entrevista e as condições de produção não são totalmente atendidas - apenas os leitores são dados: os colegas de sala e o professor.

\subsection{Análise 4: Valor social das palavras}

A abordagem do valor social das palavras faz referência aos estudos atuais da Linguística, que concebem a língua como competência comunicativa que se desenvolve no social. A seguinte orientação constitui a seção, como se pode verificar no anexo 5: "Em duplas, reescrevam os trechos lidos de $\mathrm{O}$ diário de Bridget Jones como se o enunciador fosse uma mulher de mais de 60 anos, aposentada. Usem uma folha avulsa" (FARACO; MOURA; MARUXO JÚNIOR, 2013, p. 234).

Destaca-se, ainda, a orientação dada ao professor nessa seção: "Professor, oriente os alunos a mudar o nível de linguagem, eliminando as gírias, mas mantendo uma linguagem informal” (FARACO; MOURA; MARUXO JÚNIOR, 2013, p. 234). Ao comparar o título da seção com a orientação ao professor, constata-se que há confusão entre os conceitos de língua como prática social e o nível de formalidade na língua escrita. O primeiro conceito constitui os eventos discursivos que engendram questões como ideologia e estrutura social; já o segundo conceito envolve situações de uso da língua, que, no caso da escrita, pode assumir níveis de formalidade que vão desde o informal até o mais formal, dependendo do gênero/ situação de uso. Além disso, a reescrita do texto remete à antiga "redação pela redação" do ensino tradicional de Língua Portuguesa, em que os alunos escrevem ou reescrevem determinado texto, sem que haja um destinatário. Dessa forma, não há o cumprimento das condições de produção da proposta de produção, na qual falta um propósito, um leitor e uma situação comunicativa que, no mínimo, simule uma prática social e uma situação comunicativa que justifique a mudança de nível de linguagem. 
É importante observar que a seção Prática de linguagem - "Valor social das palavras" está contextualizada no capítulo 8 , que trata do gênero textual diário pessoal. Considerando que em textos como os relatos de viagem e os diários existe um eu que se projeta no texto, as formas verbais de primeira pessoa ou o emprego de pronomes constituem uma entidade - o enunciador - que poderia ser trabalhada na seção. Assim, a língua como atividade social poderia ser abordada na análise de textos, já que o enunciador deixa marcas que ultrapassam o nível de formalidade da escrita.

\section{Considerações finais}

Este artigo pretendeu analisar, com base na leitura do livro didático Língua Portuguesa: linguagem e interação, de Carlos Emílio Faraco, Francisco Marto de Moura e José Hamilton Maruxo Júnior, da Editora Ática, como é desenvolvida a análise linguística em materiais didáticos de Língua Portuguesa.

Constatou-se, no livro analisado, que a prática de análise linguística é pouco desenvolvida na seção que se propõe a fazê-la, isto é, ainda que no manual do professor esteja explícito o objetivo da seção, qual seja, levar os alunos a refletirem sobre suas próprias práticas de linguagem, tal prática está presente em número muito pequeno, se comparado com o número de propostas de produção de textos.

Conclui-se, dessa forma, que as atividades da seção Prática de linguagem, que se propõem a promover a análise linguística, na maioria das vezes, confundem-se com simples propostas de produção de texto, as quais já têm uma seção específica intitulada Produção escrita. Esse fato revela que os autores não subsidiam satisfatoriamente o trabalho do professor no que tange ao desenvolvimento da prática de análise de língua que se faz necessária nas aulas de Língua Portuguesa.

Os diferentes gêneros textuais enfocados em cada capítulo, por sua vez, não contribuem, na maioria das vezes, para a promoção da prática de análise linguística do conteúdo discursivo-gramatical trabalhado. Em poucas atividades as propostas de produções textuais estão contextualizadas conforme as condições de produção adequadas, o que não contribui para uma análise de língua voltada para as diversas situações de comunicação.

Assim, a seção analisada do livro selecionado propõe tanto questões com perspectiva gramatical quanto questões amplas a propósito do texto, entre as quais vale a pena citar: análise dos recursos expressivos utilizados, investigação dos sentidos construídos imbricada ao contexto. 
Deseja-se, por fim, que esta pesquisa tenha contribuído com o grande número de análises de livros didáticos de Língua Portuguesa que vêm sendo divulgadas na comunidade acadêmica.

\section{Referências}

BAGNO, M. Gramática pedagógica do português brasileiro. São Paulo: Parábola, 2011. . Preconceito linguístico: o que é, como se faz. 49. ed. São Paulo: Loyola, 2007. . Sete erros aos quatro ventos - a variação linguística no ensino de português. São Paulo: Parábola, 2013.

BAKHTIN, M.; VOLOCHINOV, M. Marxismo e filosofia da linguagem. 6. ed. São Paulo: Hucitec, 1992.

BATISTA, A. A. G.; ROJO, R. Livro didático de língua portuguesa, letramento e cultura da escrita. Campinas: Mercado das Letras, 2003.

BEZERRA, M. A.; REINALDO, M. A. Análise linguística: afinal, a que se refere? São Paulo: Cortez, 2013.

BITTENCOURT, C. M. F. Autores e editores de compêndios e livros de leitura (18101910). Educação e Pesquisa, v. 30, n. 3, p. 475-491, set./dez. São Paulo, 2004.

BRASIL. Decreto no 1.006, de 30 de dezembro de 1938. Estabele as condições de produção, importação e utilização do livro didático. Diário Oficial da União - Seção 1 5/1/1939, Página 277 (Publicação Original), Brasília, DF. Disponível em: http://www2. camara.leg.br/legin/fed/declei/1930-1939/decreto-lei-1006-30-dezembro-1938350741-norma-pe.html. Acesso em: 4 jul. 2017.

BRASIL. Ministério da Educação. Guia de Livros Didáticos PNLD 2014: Língua Portuguesa. Brasília: MEC. Disponível em: http://www.fnde.gov.br/programas/livrodidatico/guias-do-pnld/item/4661-guia-pnld-2014. Acesso em: 4 jul. 2017.

BRASIL. Ministério da Educação. Guia de Livros Didáticos PNLD 2015: Língua Portuguesa. Brasília: MEC. Disponível em: http://www.fnde.gov.br/programas/livrodidatico/guias-do-pnld/item/5940-guia-pnld-2015. Acesso em: 4 jul. 2017.

BORGES, J. N. Alguns comentários sobre a iniciação científica na área de estudos linguísticos. Anais... In: Encontro do CelSul, n. 10. Cascavel: Unioeste, 2012.

CASTILHO, A. T. Nova Gramática do Português Brasileiro. São Paulo: Contexto, 2014.

COSTA VAL, M. G.; MARCUSCHI, B. (Org.). Livros didáticos de língua portuguesa: letramento, inclusão e cidadania. Belo Horizonte: Autêntica, 2005.

DIONISIO, A. P.; BEZERRA, M. A. O livro didático de Português: múltiplos olhares. 2. ed. Rio de Janeiro: Lucerna, 2003.

DIONISIO, A. P. Livros didáticos de Português formam professores? In: CONGRESSO 
BRASILEIRODEQUALIDADENAEDUCAÇÃO:FORMAÇÃODEPROFESSORES, 1. 2001: Brasília. Simpósio 6. Brasília: MEC, SEF, 2002. Disponível em: http://portal. mec.gov.br/seb/arquivos/pdf/volla.pdf. Acesso em: 4 jul. 2017.

FARACO, C.E.; MOURA, F. M.; MARUXO JÚNIOR, J.A.Língua Portuguesa: linguagem e interação. 2. ed. São Paulo: Ática, 2013.

FNDE - Fundo Nacional de Desenvolvimento da Educação. Ministério da Educação. Disponível em: http://www.fnde.gov.br/programas/livro-didatico/livro-didaticohistorico. Acesso em: 16 abr. 2015.

FRANCHI, C. Linguagem - atividade constitutiva. Almanaque, v. 5, São Paulo, p 9-26, 1987.

GERALDI, J. W. Prática da leitura na escola. In: (Org.). O texto em sala de aula. São Paulo: Ática, 2001, p. 88-103.

. Linguagem e ensino. Exercícios de militância e divulgação. Campinas: Mercado de Letras, 2002.

. Concepções de linguagem e ensino de português. In: . (Org.). O texto na sala de aula. 4. ed. São Paulo: Ática, 2003a.

. Unidades básicas do ensino de português. In: . (Org.). O texto na sala de aula. 4. ed. São Paulo: Ática, 2003b.

. Portos de passagem. 4. ed. São Paulo: Martins Fontes, 2006.

LAKATOS, E. M.; MARCONI, M. A. Fundamentos de metodologia científica. São Paulo: Atlas, 2001.

MARCUSCHI, E. Os destinos da avaliação no manual do professor. In: DIONÍSIO, A. P.; BEZERRA, M. A. (Org.). O livro didático de Português: múltiplos olhares. 2 ed. Rio de Janeiro: Lucerna, 2002.

MARCUSCHI, L. A. Produção textual, análise de gêneros e compreensão. São Paulo: Parábola, 2008.

MINISTÉRIO DA EDUCAÇÃO E DO DESPORTO. Parâmetros Curriculares Nacionais: terceiro e quarto ciclos do ensino fundamental: Língua Portuguesa. Brasília: Secretaria de Educação Fundamental, 1998.

NEDER, M. L. C. Concepções de Linguagem e o ensino de língua portuguesa. Revista Polifonia, v. 00, UFMT, 1993.

PARANÁ, Secretaria de Estado da Educação. Diretrizes Curriculares da Educação Básica: Língua Portuguesa. Curitiba, 2008.

SILVA,N.S.Ensino TradicionaldeGramática ouPráticadeAnáliseLinguística:umaquestão de (com)tradição nas aulas de português. RBLA, v. 10, n. 4. p. 949-973, 2010. Disponível em: http://www.scielo.br/scielo.php?pid=S1984-63982010000400007\&script=sci_ arttext. Acesso em: 4 jul. 2017. 
TRAVAGLIA, L. C. Gramática e interação: uma proposta para o ensino de gramática no $1^{\circ}$ e $2^{\circ}$ graus. São Paulo: Cortez, 1996.

Gramática e interação: uma proposta para o ensino de gramática no $1^{\circ}$ e $2^{\circ}$ graus. 6a ed. São Paulo: Cortez, 2001.

Data de submissão: 01/08/2017

Data de aceite: $22 / 10 / 2017$ 


\section{Anexo 1}

\section{Prática de linguagem}

\section{$\gg$ Expressões que marcam o ritmo da narrativa}

1 Observe a imagem a seguir e imagine uma história sobre ela que faça sentido.

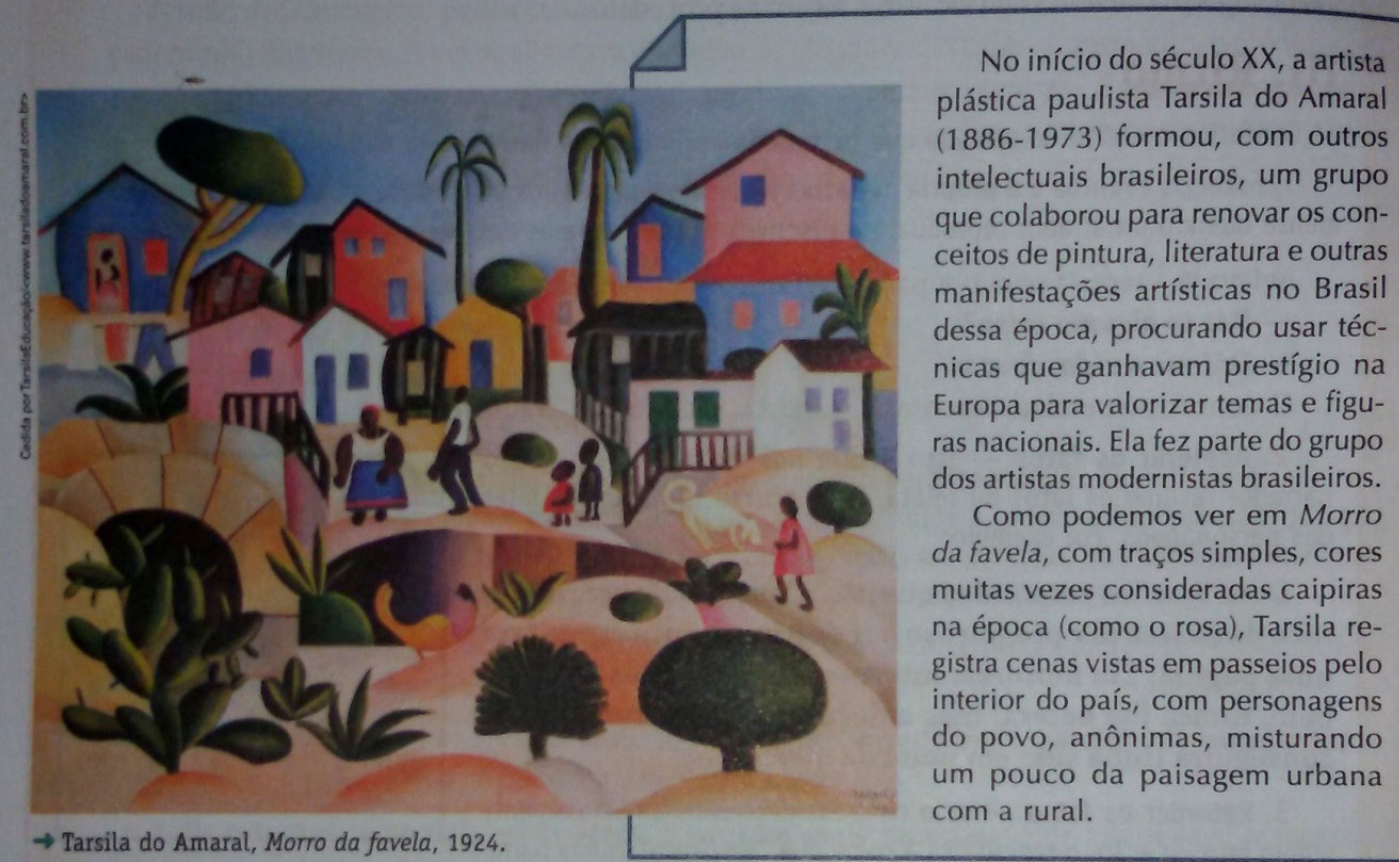

a) Inicie, numa folha avulsa, uma narrativa contando o que ocorre com as personagens da tela.

b) Nessa narrativa, promova um retorno temporal para explicar um fato que antecedeu ao momento represen tado na pintura.

c) Controle o ritmo de sua narrativa, inserindo sequências de aceleração ou retardamento.

d) Se quiser, insira descrições ou diálogos, para ajudar a construir o ritmo indicado.

2 A seguir, há algumas expressões que podem ser utilizadas para marcar a cronologia e o ritmo de uma narrativa. Reúna-se com mais cinco colegas e utilizem-nas, na ordem em que aparecem, para produzir oralmente uma história coletiva.

Professor, se possivel, organize os alunos em grupos de cinco pessoas.

Naquela manhã de agosto...

E assim, durante os meses que se passaram,...
Logo em seguida...

Hoje...
Mas dias antes... De repente...

a) Procedam desta forma: um aluno começa a história, a partir da primeira expressão; um segundo aluno prossegue de onde o primeiro parou, utilizando a segunda expressão e dando continuidade à história; e assim por diante, até que todas as expressões tenham sido empregadas.

b) Depois do trabalho oral, a história criada coletivamente em cada grupo deve ser registrada por escrito, para ser comparada com o trabalho dos demais grupos. Exponham as narrativas no mural da classe. 


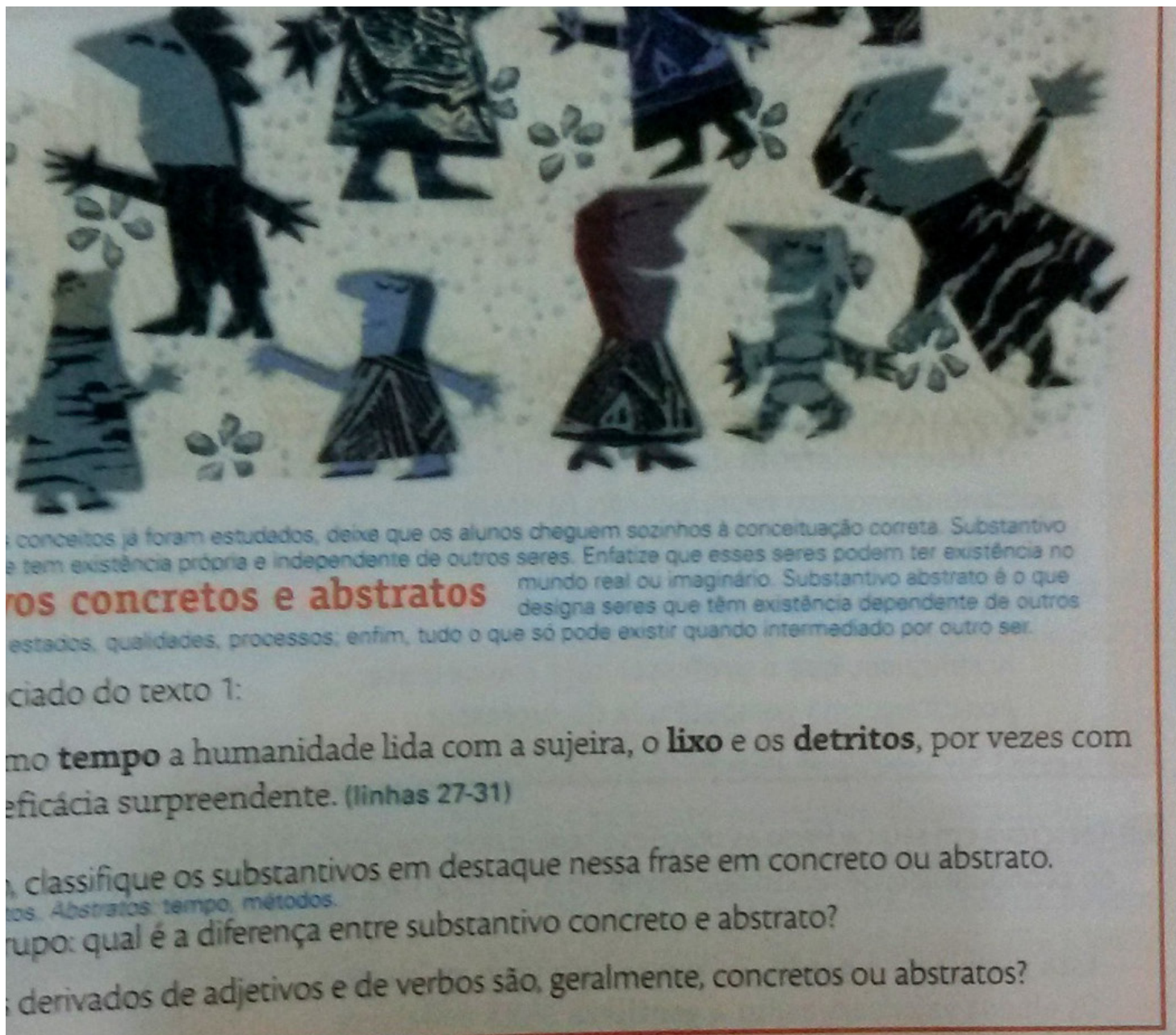

\section{inguagem}

ลี่อ

texto $2:$

no campo ou na cidade, nas casas dos ricos ou dos pobres, a morada colonial não lificadas ou à construção principal. (linhas 54-57)

tical das palavras destacadas nessa frase? suostantivo Igramavical pertencem essas duas palavras? acjetio dança de classe gramarical delas nessa construçào? O uso do antigo definido os 


\section{Anexo 2}

O processo por meio do qual é possível "transformar" palavras de outras classes em substantivo é chamado de nominalização. Esse processo permite enriquecer as descrições tornando-as mais precisas.

No quadro a seguir, vamos observar algumas maneiras de se fazer a nominalização.

\section{Uso de artigo}

0 dormir bem é essencial à saúde.

Não fique preso ao ontem.

\section{Uso de um substantivo derivado de verbo, adjetivo ou advérbio}

1. A partir de um adjetivo:

0 termo brasílico era erudito. Isso dificultou sua aceitação pelo povo.

A erudição do termo brasílico dificultou sua aceitação pelo povo.

erudiçäo (substantivo) deriva de erudito (adjetivo)

\section{A partir de um verbo:}

Inúmeras atividades se desenvolviam nas casas coloniais. Isso demonstra a importância do ambiente doméstico nesse período da nossa história.

0 desenvolvimento de inúmeras atividades nas casas coloniais demonstra a importância do ambiente doméstico nesse período de nossa história.

desenvolvimento (subst.) deriva de desenvolver (verbo)

\section{A partir de uma oração inteira:}

Acreditamos que o professor seja competente.

Acreditamos na competência do professor.

Reescreva em seu caderno as orações a seguir, nominalizando o trecho em destaque e encaixando-o no lugar do pronome isso, de modo que forme uma só frase. Faça as modificações necessárias. Observe o exemplo.

Esta professora é gentil. Os alunos valorizam muito isso. Os alunos valorizam muito a gentileza desta professora.

3) As respostas de Mariana são exatas. A classe admira isso. A classe admira a exatidao das respostas de Marrana Isso é inconcebível.

Semearam trigo em solo inadequado. Isso é in

A semeadura do ingo em solo inadequado e indonces. Isso não agrada aos eleitores.

chos

d) Carlos é irônico. A turma gosta disso.

A turma gosta da ironia de Carios.

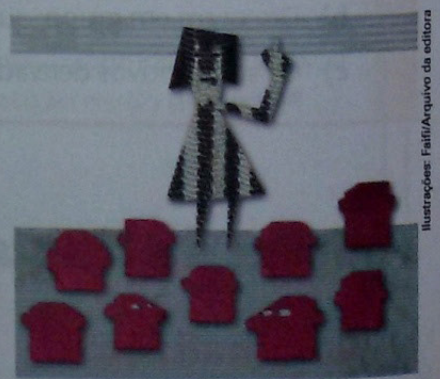

3. Transforme as frases que seguem, nominalizando as expressões em destaque. Observe o exemplo.

Não gosto de filmes de terror porque são muito violentos.

Não gosto da violência excessiva de filmes de terror.

a) Gosto dos britânicos porque são pontuais

b) Nắo gosto muito de meus colegas de classe porque são agressivos.

c) Adoramos algumas letras de música da Madonna porque são eróticas.

Adoramos arousmo de alqumas letras de música da Madonna 


\section{Nominalização e sintese de informações}

Quando se pretende retomar e resumir informações na língua escrita, a nominalização é um recurso muito útil. Leia os exemplos que seguem, extraídos de matérias de revista.

Os solavancos vividos pelo mercado financeiro [...] trouxeram a expectativa de que a economia brasileira (e mundial) crescerá mais lentamente nos próximos anos. Com esse cenário, aceito unanimemente, volta ao primeiro plano do debate a velha e indigesta questão dos gastos públicos.

O substantivo cenário retoma os elementos do enunciado anterior ("solavancos vividos pelo mercado"), resumindo-os e encaixando-os na frase seguinte.

Revista Época. São Paulo: Globo, 29 set. 2009. p. 64.

Os jogos educativos representam uma fatia cada vez maior do mercado de games. No ano passado, estima-se que tenham sido vendidas 250 mil cópias para PC. Esse número deverá dobrar em 2009.

O substantivo número retoma a expressão "250 mil cópias" do enunciado anterior. encaixando-o na frase seguinte.

Revista Epoca. São Paulo: Globo, 29 set. 2009. p. 120

Reúna-se com um colega e procurem, em reportagens de revistas, exemplos semelhantes de nominalização. Identifiquem as expressões nominalizadas que encontrarem e os termos que elas resumem ou retomam.

5 Com base no texto que segue, construa um quadro cronológico, nominalizando verbos e orações. Mais abaixo sugerimos o começo desse quadro. Copie-o no caderno e continue.

Em 21 de junho de 1839, nasce Joaquim Maria Machado de Assis, numa casa do Morro do Livramento, no Rio de Janeiro. Os pais, Maria Leopoldina e Francisco José, são agregados da quinta de dona Maria José de Mendonça, madrinha do menino.

Em 1855, Machado de Assis publica na Marmota Fluminense o poema "Ela". O dono da revista Paula Brito reúne literatos, inclusive Machado. Surge a célebre Sociedade Petalógica. Machado torna-se cronista teatral de O Espelho, em 1859.
Ministério da Agricultura, Comércio e Obras Públicas.

Em 1881, é publicado o romance Memórias póstumas de Brás Cubas. Torna-se cronista da Gazeta de Notícias.

Funda, em 1896, ao lado de dezenas de companheiros, a Academia Brasileira de Letras. Tornou-se o primeiro presidente da instituição.

Em 1908, morre de câncer na boca. É enterrado no cemitério de São João Batista, no Rio de Janeiro. Adaptado de: revista Época. São Paulo: Globo, 29 set. 2009. p. 138-140.

Frequenta teatros e se encanta por Aimée, a atriz de cancã do Alcazar Lyrique.

Casa-se com Carolina Augusta, em 1869. Saem Contos fluminenses e Falenas.

Em 1873, é nomeado primeiro oficial da Secretaria de Estado do

Segundo o Dicionário Cravo Albin da música popular brasileira, a Sociedade Petalógica do Rossio Grande foi uma instituição criada por poetas interessados em modinhas populares, que em meados do século XIX se reuniam na tipografia do editor e poeta Francisco de Paula Brito (1809-1891). A loja ficava no Rossio Grande, antigo nome da atual praça Tiradentes, e tornou-se o ponto de encontro de poetas cultuadores da modinha (entre eles, Machado de Assis e Gonçalves Dias) e compositores, instrumentistas e seresteiros da época.

Para mais informações, consulte: <www.dicionariompb.com.br/verbete. asp?tabela=T_FORM_C\&nome $=$ Sociedade + Petal\%F3gica+do+Rossio+Grande $>$.

Quadro cronológico: Machado de Assis

1839 - Nascimento no Morro do Livramento, no Rio de Janeiro.

1855 - Publicação do poema "Ela", na Marmota Fluminense. 


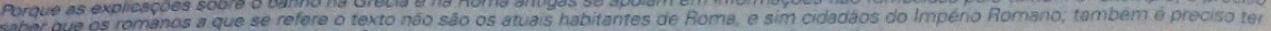
homacbes sobre esse imoeno, como o fato de o transporte de aguas ser feito por aquedutos, etc

5 Diferentemente da localização de Mohenjo-Daro, possivelmente desconhecida dos leitores, seria impossível compreender o texto sem ter nenhum conhecimento prévio sobre a história das sociedades grega e romana antigas. Por quê?

Professoltando que a leitura de um texto e retomar e complementar a questáo 2.

oleitor, ao ler, aciona determinadas estrategias cognitivas só sáo possivers porque informaçóes contextueis, preencher lacunas de sentido mobilizance

conhecimentos prévios e fazer inferéncias de sentido)

$\rightarrow$ No Japão, há quem ainda pratique o banho coletivo, que é conhecido como Sentō e vem se tornando menos comum à medida que se populariza o hábito de ter banheiras em casa. Para eles, o banho não serve apenas para a higiene, e sim para purificar a alma. Na foto, homem desfruta desse momento.

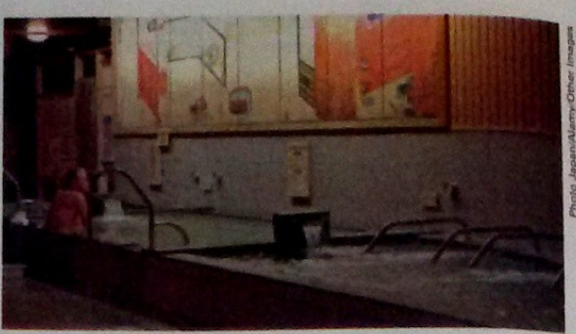

Na obra História da vida privada no Brasil, apresenta-se um panorama sobre o dia a dia e os costumes das pessoas que habitaram o Brasil no periodo colonial.

Leia o texto a seguir, extraido desse livro, para conhecer um pouco a respeito das casas e moradas brasileiras dessa época.

\section{Texto 2}

\section{O exterior da morada}

Leila Mezan Algranti

Inúmeros são os registros disponíveis sobre as moradas coloniais tanto no mundo rural como no urbano. Cronistas e viajantes, percorrendo o Brasil entre os séculos XVI e XIX, deixaram suas im5 pressões escritas e iconográficas sobre a forma de morar dos colonos, apontando para as profundas diferenças existentes em tão vasto território. Elas destacam não apenas a diversidade dos materiais utilizados na construção, mas também aquela existente no partido arquitetônico, na divisão interna, na forma de morar dos mais humildes e dos mais privilegiados. Embora a morada tenha primeiramente a função de dar abrigo e re-

iconográfico: referente a imagem

partido arquitetônico: as diretrizes formais de uma construção, levando em conta: a técnica construtiva, o clima, as condições físicas e topográficas do local, as exigências dos costumes populares e/ou conveniência do empreendedor, as condiçōes financeiras do empreendedor, a legislação e/ou normas sociais em questão

pouso a seus habitantes, ela é também o local onde inúmeras atividades se desenvolvem no dia a 15 dia. [...] seu aspecto exterior não deve ser negligenciado, uma vez que o entorno e as características arquitetônicas podem revelar, à primeira vista, aspectos importantes da vida de seus moradores.

Nas vilas e cidades, por exemplo, nos três pri- 20 meiros séculos da colonização, o aspecto das moradas apresenta-se bastante simples e pobre, uma vez que eram povoadas por pessoas com poucos

Dirigida pelo historiador Fernando Novais, a coleção História da vida privada no Brasil comenta e descreve aspectos variados dos costumes brasileiros em diversos períodos da história: procura dar uma ideia de como viviam as pessoas, que atividades desenvolviam, como se organizavam as cidades e o meio rural, quais eram as divisões sociais e a hierarquia que se estabelecia entre elas, além de muitos outros aspectos.

0 volume em que se encontra o texto que você leu foi organizado pela historiadora Laura de Mello e Souza e concentra-se na História do Brasil durante o período em que estas terras eram chamadas de América portuguesa (do século XVI ao início do XIX).

Leila Mezan Algranti, autora do texto, também é historiadora e professora universitária. recursos, e visitadas ocasionalmente por proprietários de sítios e fa- 25 zendas que necessitavam apenas um abrigo para estadias passageiras. Encontramos, assim, certa homogeneidade nas construções urbanas, como casas de tamanho mais 30 reduzido, de apenas um andar, nas quais predominavam os materiais disponíveis na região, como barro, madeira ou pedras. Os sobrados e as vivendas, ocupados pelos mem- 35 bros da elite, surgiram mais tarde, em consequência da diversificação 
da economia e do crescimento urbano. Já no início do século XIX, o viajante inglês Luccock registrava 40 no Rio de Janeiro a sobrevivência das casas dos primeiros tempos: "Muitas das casas possuem somente um andar"; Leithold e Rango confirmavam que a maioria das casas eram térreas, mas que, além destas, havia outras de dois, três e quatro pavimen-

45 tos, com balcões de ferro ou madeira. O caráter essencialmente agricola da economia colonial deixava, assim, suas marcas na arquitetura.

Segundo Carlos Lemos [arquiteto], a morada urbana se manteve mais fiel à arquitetura portuguesa, 50 pelo menos na aparência, embora não descartasse as influências indigenas e as adaptações dos colonos quanto ao modo de morar; já nas propriedades rurais a falta de uniformidade foi mais marcante.

De qualquer forma, no campo ou na cidade, nas 55 casas dos ricos ou dos pobres, a morada colonial não se restringia às áreas edificadas, ou à construção principal. Quintais, jardins, pomares e hortas, além de anexos, estes cobertos de telhas ou palha, eram geralmente circundados por muros baixos 60 que delimitavam o espaço doméstico. $\mathrm{Na}$ São Paulo dos bandeirantes, os inventários de seus moradores referem-se com frequência a esses espaços. O inventário de Francisco de Almeida, por exemplo, registrava em 1616: "casas da vila, dois lanços 65 de taipa de mão, cobertas de telha com o quintal".

ALCRANTL, Leila Mezan. Familias e vida doméstica. In: MELLOE SOUZA Lara de (Org) Histónia da vida privada no Brasil. Sảo Paulo Companhia das Letras, 1997. v. 1. p. $90-91$
John Luccock (inglês). T. von Leithold e L. von Rango (prussianos) visitaram o Brasil no inicio do século XIX, quando aqui se instalou a familia real portuguesa. A partir do que viram na capital e em outras regióes, traçaram um relato do que observaram e produziram desenhos, o que foi registrado em alguns livros, entre os quais Notas sobre o Rio de laneiro e partes meridionais do Brasil, de Luccock, e O Rio de laneiro visto por dois prussianos em 1819, de Leithold e Rango.

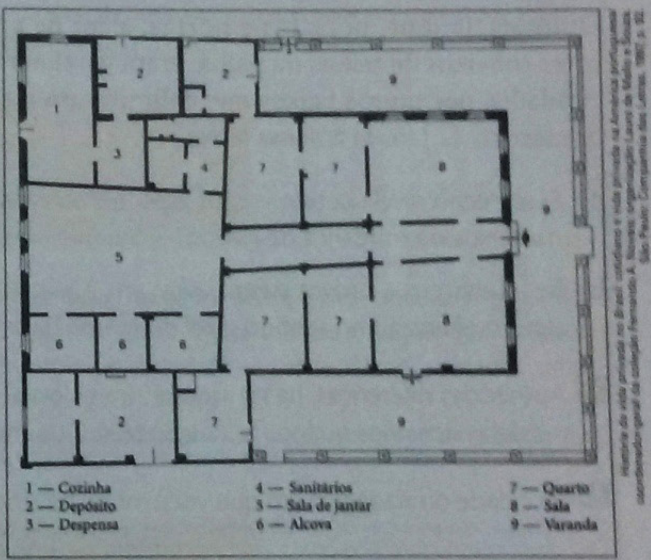

$\rightarrow$ Exemplo de casa-grande com varanda em seus très lados. Engenho São Roque, Maragogipe, Bahia.
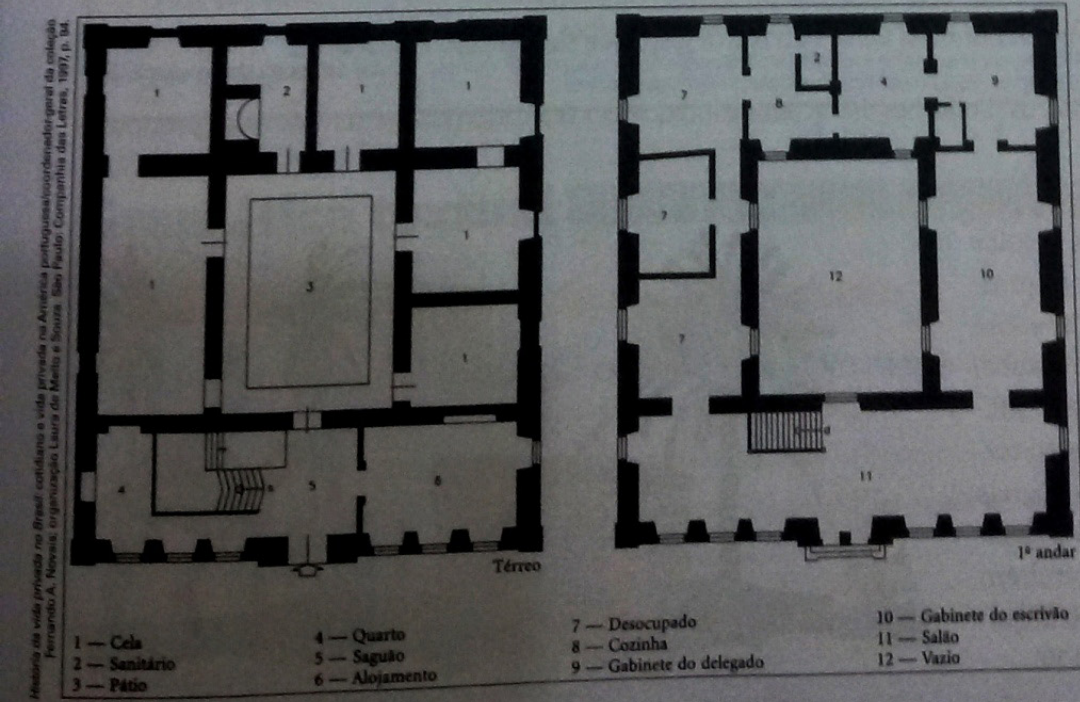

anexo: parte complementar, que se liga a principal.

$\rightarrow$ Casa-grande dotada de pátio interno, essencial à ventilaçăo. que permitia enfrentar os dias mais quentes. Engenho de Joào Rodrigues Adomo, Cachoeira. Bahia. 


\section{Anexo 3}

\section{Prática de linguagem}

\section{\Modalização e advérbios}

Muitos advérbios que modificam toda a frase têm uma caracteristica especial: exprimem o ponto de vista do enunciador a respeito do fato que ele expõe. Observe alguns exemplos:

Realmente Cuiabá é uma cidade muito quente.

$O$ advérbio realmente indica que o enunciador confirma o fato.

Talvez eu vá a Recife nas próximas férias.

0 advérbio talvez revela a dúvida do enunciador a respeito do fato

Ela provavelmente vai se demitir da empresa amanhã.

0 advérbio provavelmente nāo se refere ao verbo demitir-se em si, e

sim coloca em dúvida o fato todo expresso no enunciado.

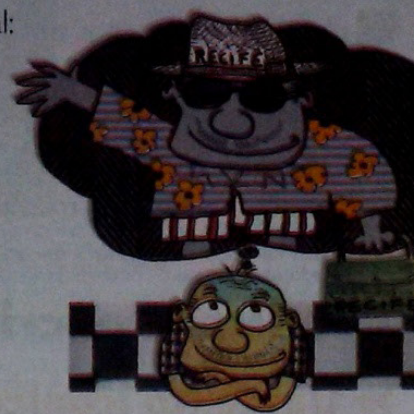

A expressão do ponto de vista do enunciador em relação a um fato é o que chamamos de modalização. A modalização é a projeção, no enunciado, de marcas explícitas da opinião do enunciador.

Por ser frequente nos textos em que o enunciador deixa clara sua opinião a respeito do assunto tratado, ela é bastante comum em textos argumentativos.

A seguir, leia trechos de uma entrevista publicada pela revista Galileu com dois pesquisadores norte-americanos - Lawrence e Cheryl - que defendem os videogames violentos, alegando que esses jogos podem contribuir para que crianças e jovens se tornem moralmente mais responsáveis. Alguns advérbios e expressões de natureza adverbial (isto é, expressões que podem funcionar como advérbios), modalizadores ou não, estão em destaque.

GALILEU: Por que crianças e jovens gostam de jogar games violentos?

Lawrence: É muito interessante quando conversamos com crianças em sessões de grupo. Muitos respondem que violência não interessa, mas o que chama a atenção é o mundo complexo de certos games e seus personagens elaborados.

Cheryl: Até acredito que as crianças sintam-se um pouco atraídas pela violência dos games, mas não do jeito negativo que as pessoas pensam. Nossa cultura tem uma longa tradição de entretenimento violento, seja vindo de histórias mitológicas ou contos de fada. Alguns adolescentes usam o videogame para suprir uma curiosidade que eles têm de conhecer um mundo de regras sociais diferentes e querem fazer isso da maneira mais segura possível. Algumas crianças disseram que os games as ensinaram sobre as consequências de quem faz algo errado. Elas são atentas a isso e conseguem discernir muito bem o mundo real do irreal.

GALILEU: E as garotas, o que elas procuram nesses games?
Lawrence: Também gostaríamos de saber [risos]. Começamos nossa pesquisa acreditando que as garotas não eram tão interessadas nisso, mas aprendemos rapidinho que estávamos enganados. Uma coisa que descobrimos é que elas procuram algo diferente num jogo violento. De fato, elas não estão interessadas em acumular pontos ou subir na hierarquia do jogo. Elas querem é explorar os cenários.

GALILEU: Os pais devem jogar videogames com os filhos?

Cheryl: Sim, mas há um problema: a geração atual de pais não sabe manusear os controles com destreza. E temos a certeza de que essa geração de crianças também terá problemas com os controles do futuro. Jogar com o filho é uma ótima oportunidade de relacionamento. É uma das poucas áreas em que os adolescentes se sentem superiores a seus pais. Às vezes, a presença dos pais ajuda muito para explicar alguma referência que os filhos desconheçam.

Adaptado de: revista Galileu. Rio de Janeiro: Globo, jun. 2008. p. 16-17. 
Reúna-se com alguns colegas e observem os argumentos expostos pelos pesquisadores. Tentem explicar de

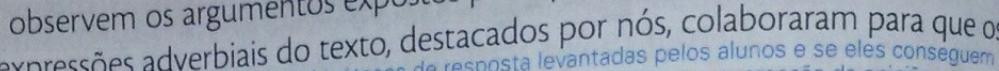

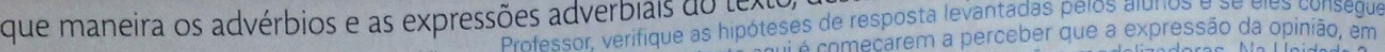
cientistas expusessem suas opiniões.

justifica-las. Oimpor natureza está as

retoma-se o estudo de modalizaçăo. Utilizando ao menos três advérbios ou expressões adverbiais destacados ná é opinião sobre a questão: caderno produza um parágrafo, de mais ou menos oito lin os videogames incentivam ou não a violência? Os leitores desse p Compare seu parágrafo com o de seus colegas. Verifiquem se há muitas coincidências de uso, ou seja, se muitos 列 de vocês utilizaram as mesmas expressões ou advérbios. Em caso afirmative, Les expressōes adverbiais empregados, e Professor, vocé pode promover um momento de socializaçáo das respostas, anotando na lousa os advexpressōes mais frequentes provavelmente seräo fazer o levantamento da frequência de uso. Como se trata de um paragrafo opinativo, os adverador dos advérbios e expressōes anotados.

\section{Produção escrita}

\section{$\gg$ Um texto icônico-verbal: a capa de CD}

No capítulo anterior, foi sugerido que você e seus colegas compusessem letras de música e as cantassem em certo momento. Foi proposto também que fosse feita uma gravação (em áudio e/ou vídeo) do festival. Agora a ideia é registrar essa gravação num CD (ou DVD) e produzir uma capa.

Professor, intormacōes sobire os CDs de musica: Uakti e Tabinha. Mulungu do cerrado. Uakti e Tabinha, 2000; Música de cinema. Caras, s/d, v. 4 (nesila página); Aurio Corrá Quietude. Alquimusic, 1995 (na página seguinte)

11 Observe atentamente as capas a seguir:
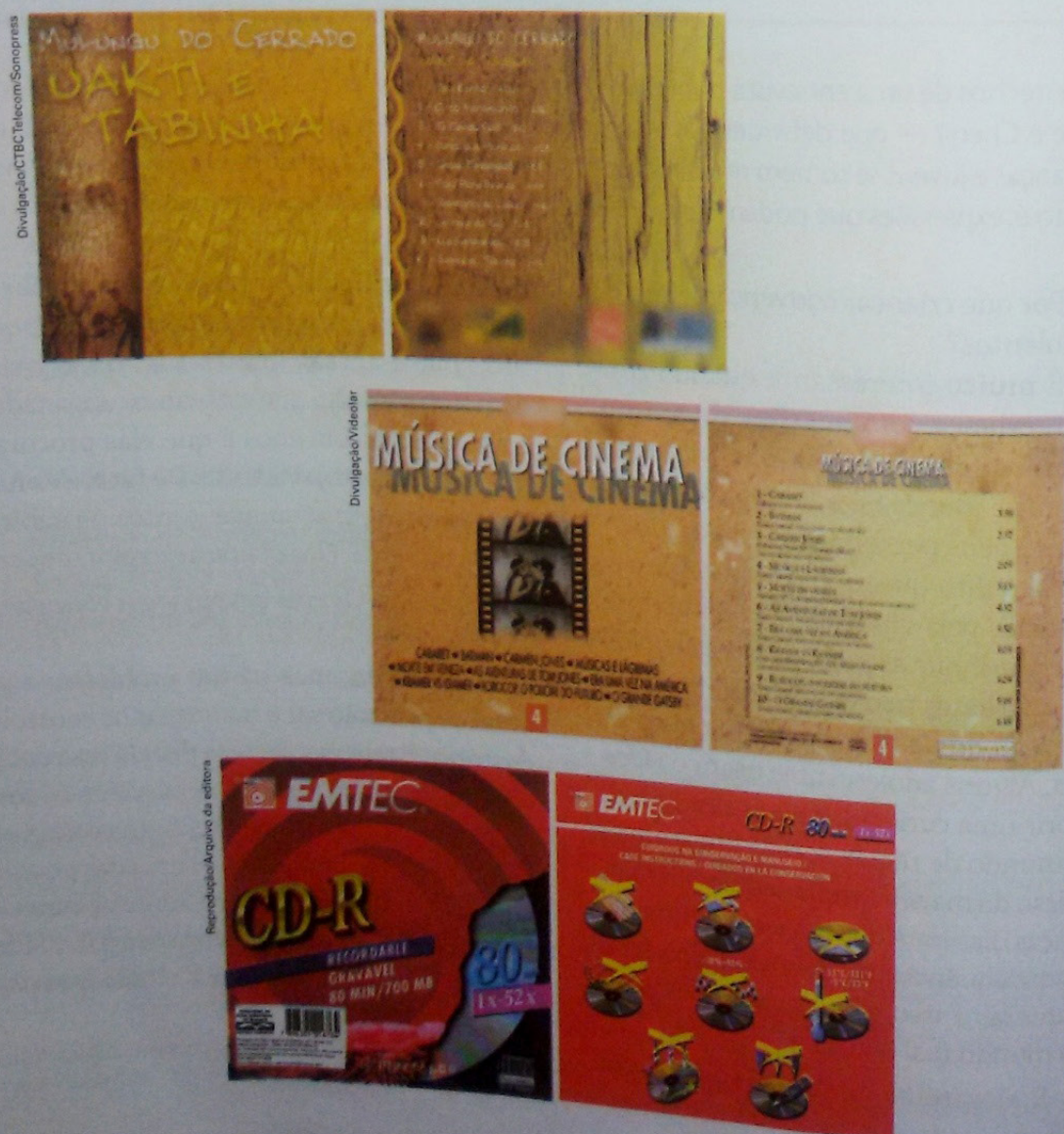


\section{Anexo 4}

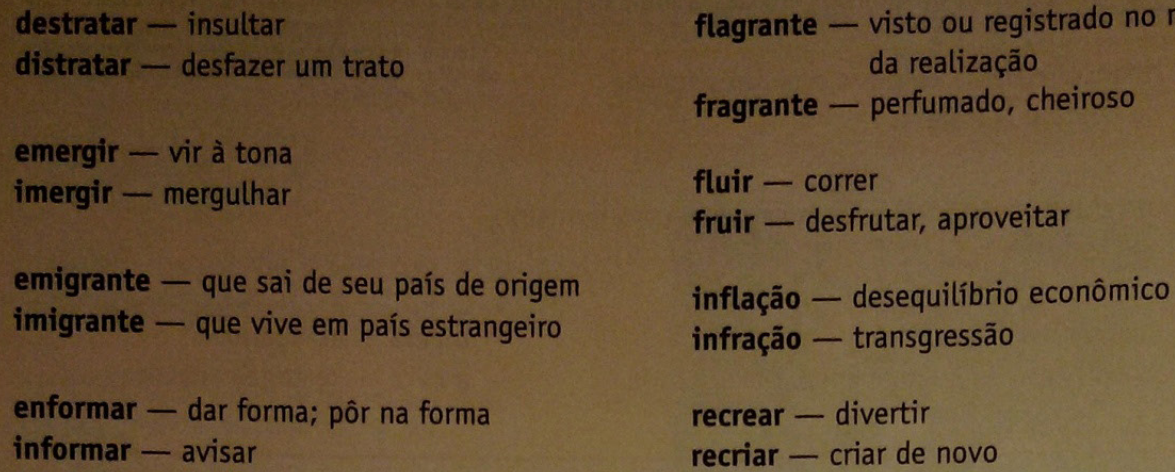

Reescreva estas frases no caderno, substituindo os termos e expressões em destaque por um dos parônimos do quadro acima.

a) O juiz queria conceder o pedido do réu. deferir

b) O prazo da entrega das notas precisa ser adiado. diferido

c) O corpo do homem que morreu afogado ainda não veio à tona. emergiu

d) O casal foi inocentado. descriminado ou descriminalizado

e) Minha namorada veste-se com muito comedimento. discriçäo

f) O rio corre silencioso durante a noite. flu

g) Muitas pessoas não conseguem desfrutar as vantagens da aposentadoria. fruir

10 Nas frases que seguem, há palavras empregadas indevidamente em lugar de seus parônimos. Identifique os erros e corrija-os, reescrevendo as frases em seu caderno.

a) É comum ouvir dizer que no Brasil já não existe racismo, preconceito ou descriminação.

b) O ministro da Saúde quer avaliar com cautela o debate em torno da discriminação de alguns medicamentos proibidos.

c) Você acaba de infligir as regras da escola. Por isso, o diretor vai infringir-lhe um castigo.

d) Este perfume tem uma suave flagrância. fragrància

e) O ladrão foi preso em fragrante. flagrante

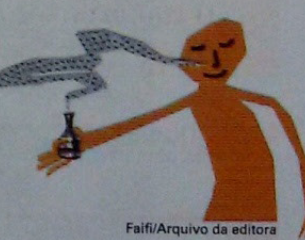

11 Reúna-se com alguns colegas e pesquisem, em revistas e jornais, frases em que há exemplos de homonímia e de paronímia. Troquem as frases encontradas com os outros grupos. No final, uma equipe fica responsável por fazer uma coletânea do resultado da pesquisa e distribuir para toda a turma.

\section{Prática de linguagem}

\section{$\gg$ Valor social das palavras}

Will Em duplas, reescrevam os trechos lidos de O diário de Bridget Jones como se o enunciador fosse uma mulher de mais de 60 anos, aposentada. Usem uma folha avulsa. 